\title{
A Novel Current Controlled Space Vector Modulation based Control Scheme for Reducing Torque Ripple in Brushless DC Drives
}

\author{
V.Viswanathan \\ Research Scholar, \\ Department of EEE \\ JNTU, Hyderabad, India
}

\author{
Dr.S.Jeevananthan \\ Professor, \\ Department of EEE, \\ Pondicherry University, India
}

\begin{abstract}
A novel Current Controlled Space Vector Pulse Width Modulation (CCSVPWM) technique for Brushless Direct Current (BLDC) motor drives, with a view to reduce torque ripple is proposed. The current ripple, created due to the stator winding inductance, leads to generation of ripple in the torque and prevents the usage of BLDC motor in a precise servo drive system. The paper includes MATLAB/SIMULINK results of conventional, unipolar, bipolar current control algorithms (CCAs), varying input voltage method (VIVM) and a new CCSVPWM approach. The comparison of simulation results reveal that the CCSVPWM technique is effective in reducing the ripple. This control method improves the system performance with low torque ripple thus making it suitable for immense applications employing electromechanical actuators.
\end{abstract}

\section{Keywords}

Brushless DC motor, current controlled SVPWM technique, torque ripple reduction.

\section{INTRODUCTION}

Brushless Direct Current (BLDC) motors are one of the motor types rapidly gaining popularity. BLDC motors have some advantages over conventional brushed DC motors and induction motors. Some of these are; better speed versus torque characteristics, high dynamic response, high efficiency, long operating life, noiseless operation and higher speed ranges. In addition, BLDC motors are reliable, easy to control, and inexpensive. Due to their favorable electrical and mechanical properties, BLDC motors increasingly are being used in computer, automotive, aerospace, industrial and household products because of its high power density, compactness, low maintenance and ease of control. In spite of their advantages, they show some drawbacks: stator current commutation torque ripples which occur due to the loss of ideal phase current commutation.

An idealized brushless dc motor has a trapezoidal back electromotive force (EMF) waveform. For this back EMF waveform it can be shown that zero torque ripple is produced when the motor is fed by a rectangular current waveform [1].However, in a practical BLDC drive, since machines has both inductance and resistance, the stator currents are different from the ideal case and the currents reach to their final values

with delay. In other words, circuit has a time constant. Therefore, the current ripple is produced by influence of the inductance and the torque ripple is affected by current ripple directly [2]. The torque ripple generated in commutation period is the main drawback of BLDC motor which deteriorates the precision of BLDC motor [3], [4].Therefore, the torque ripple minimization or elimination is a considerable issue in BLDC motor drives. Several theoretical approaches for analysis of the commutation torque ripple have been reported in literature [5], [6]. A direct torque control (DTC) by employing a hybrid 2phase and 3-phase switching mode during the commutation periods was presented in [7]. Commutation torque ripple reduction was reported in [8] which based on a fact that current slopes of the incoming and outgoing phases during the commutation interval can be equalized by a proper duty-ratio control. Adaptive torque ripple control for current shaping during commutation was proposed in [9]. A current control method has been presented in [10] to reduce torque ripple. However, torque ripple caused by commutation is not fully considered in [11]. In [12], the commutation torque is reduced by changing the DC-link voltage which requires additional DClink voltage control circuit and capacitors, and thereby increasing the cost. A method for commutation torque ripple minimization in direct torque controlled BLDC drives is presented in [13]. A hardware polynomial based profile generator was used for minimizing the torque. Novel resonant pole inverter for Brushless DC motor drive system is presented in [14].

A PWM control algorithm for eliminating torque ripple caused by stator magnetic field jump of brushless DC motors is proposed by [15]. Reference [16] proposed a PWM chopping method to improve the torque ripple for brushless DC miniature motors. Reference [17] discussed the influences of PWM mode on the current generated by back-EMF of switch off phase in BLDC motor. Three-phase PWM techniques are presented to reduce the commutation torque ripple in[18-20]. Several PWM techniques [21-22] have been proposed to eliminate reversal DC-link current or circulating current of BLDC motor drives. In this paper, a current controlled Space Vector PWM technique for torque ripple reduction is proposed. 


\section{SVPWM FOR BLDC MOTOR}

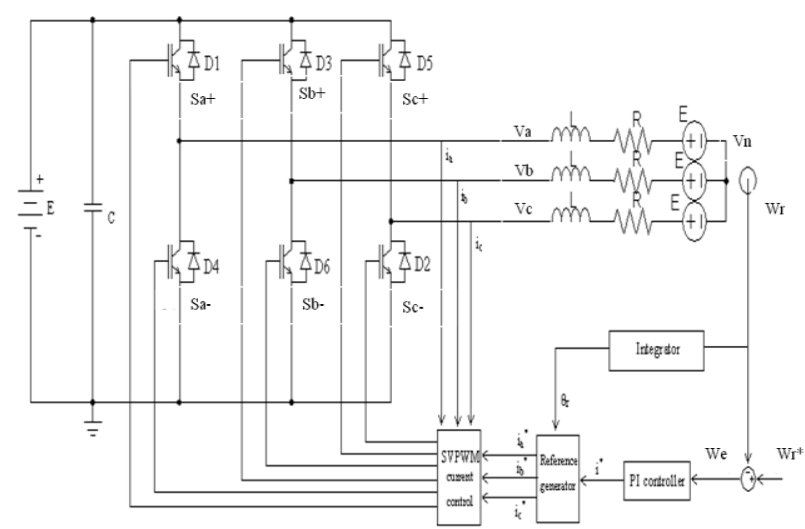

Fig 1: Block diagram of BLDC motor drive

Figure 1 shows the typical structure of a BLDC motor connected to a Voltage Source Inverter. Since the motor is considered as a balanced load with an unconnected neutral,

$$
\begin{aligned}
& V_{n}=\left(V_{a}+V_{b}+V_{c}\right) / 3 \\
& V_{a n}=V_{a}-V_{n}=\left(V_{a b}-V_{c a}\right) / 3, \\
& V_{b n}=V_{b}-V_{n}=\left(V_{b c}-V_{a b}\right) / 3 \text { and } \\
& V_{c n}=V_{c}-V_{n}=\left(V_{c a}-V_{b c}\right) / 3
\end{aligned}
$$

For this three phase power inverter, there are eight possible switching states. Six of them lead to non-zero phase voltages and the two interchangeable states lead to zero phase voltages. When mapped in a 2D-frame fixed to the stator using Concordia transformation [23], the six non-zero phase voltages form the vertices of a hexagon as shown in Figure 2.

$$
\left[\begin{array}{c}
\mathrm{V}_{\alpha} \\
\mathrm{V}_{\beta}
\end{array}\right]=\left[\begin{array}{ccc}
1 & -\frac{1}{2} & -\frac{1}{2} \\
0 & \frac{\sqrt{3}}{2} & -\frac{\sqrt{3}}{2}
\end{array}\right] \times\left[\begin{array}{c}
\mathrm{V}_{\mathrm{an}} \\
\mathrm{V}_{\mathrm{bn}} \\
\mathrm{V}_{\mathrm{cn}}
\end{array}\right]
$$

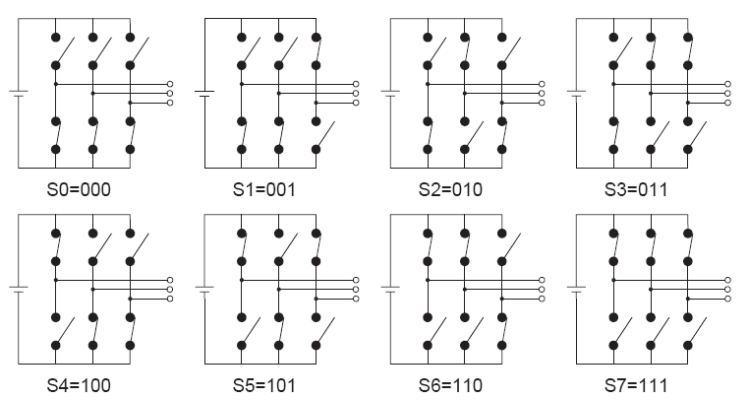

Fig 2: Possible switching configuration of a three phase inverter
In complex form, these non-zero phase voltages can be written as $\mathrm{V}_{\mathrm{k}}=\mathrm{Ee} \mathrm{j}^{\mathrm{j}(\mathrm{k}-1) \frac{\pi}{3}}$, with $\mathrm{k}=1$ to 6 and $\mathrm{V}_{0}=\mathrm{V}_{7}=0 \mathrm{~V}$. The line-to-line and line-to-neutral voltages in each of the eight possible configurations of the inverter are shown in Table 1.

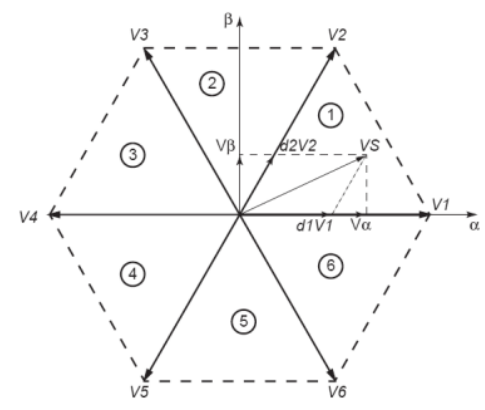

Fig 3: Eight possible switching configurations in the Concordia reference frame

Table 1. Switching configurations and output voltages of a 3phase inverter

\begin{tabular}{|c|c|c|c|c|c|c|c|c|c|c|c|c|}
\hline$S_{a+}$ & $S_{b+}$ & $S_{c+}$ & $S_{1}$ & $V_{a b}$ & $V_{b c}$ & $V_{c a}$ & $V_{a n}$ & $V_{b n}$ & $V_{c n}$ & $V_{a}$ & $V_{\beta}$ & $V_{i}$ \\
\hline 0 & 0 & 0 & $S_{0}$ & 0 & 0 & 0 & 0 & 0 & 0 & 0 & 0 & $V_{0}$ \\
\hline 0 & 0 & 1 & $S_{1}$ & 0 & $-E$ & $E$ & $-E / 3$ & $-E / 3$ & $2 E / 3$ & $-E / 2$ & $-\sqrt{3} E / 2$ & $V_{5}$ \\
\hline 0 & 1 & 0 & $S_{2}$ & $-E$ & $E$ & 0 & $-E / 3$ & $2 E / 3$ & $-E / 3$ & $-E / 2$ & $\sqrt{3} E / 2$ & $V_{3}$ \\
\hline 0 & 1 & 1 & $S_{3}$ & $-E$ & 0 & $E$ & $-2 E / 3$ & $-E / 3$ & $-E / 3$ & $-E$ & 0 & $V_{4}$ \\
\hline 1 & 0 & 0 & $S_{4}$ & $E$ & 0 & $-E$ & $2 E / 3$ & $-E / 3$ & $-E / 3$ & $E$ & 0 & $V_{1}$ \\
\hline 1 & 0 & 1 & $S_{5}$ & $E$ & $-E$ & 0 & $E / 3$ & $-2 E / 3$ & $E / 3$ & $E / 2$ & $-\sqrt{3} E / 2$ & $V_{6}$ \\
\hline 1 & 1 & 0 & $S_{6}$ & 0 & $E$ & $-E$ & $E / 3$ & $E / 3$ & $-2 E / 3$ & $E / 2$ & $\sqrt{3} E / 2$ & $V_{2}$ \\
\hline 1 & 1 & 1 & $S_{7}$ & 0 & 0 & 0 & 0 & 0 & 0 & 0 & 0 & $V_{7}$ \\
\hline
\end{tabular}

In the Concordia frame(see Figure 3), any stator voltage, $\mathrm{V}_{\text {ref }}=\mathrm{V}_{\alpha}+\mathrm{j} \mathrm{V}_{\beta}=\mathrm{V}_{\mathrm{sm}} \cos (\theta)+\mathrm{j} \mathrm{V}_{\mathrm{sm}} \sin (\theta) \quad$ located inside the hexagon belongs to one of the six sectors, and can be expressed as a linear combination of the two non-zero phase voltages which delimits the sector $\mathrm{V}_{\mathrm{s}}=\mathrm{d}_{\mathrm{k}} \mathrm{V}_{\mathrm{k}}+\mathrm{d}_{\mathrm{k}+1} \mathrm{~V}_{\mathrm{k}+1}$. Equating $\mathrm{d}_{\mathrm{k}} \mathrm{V}_{\mathrm{k}}+\mathrm{d}_{\mathrm{k}+1} \mathrm{~V}_{\mathrm{k}+1}$ to $\mathrm{V}_{\mathrm{sm}} \cos (\theta)+\mathrm{j}_{\mathrm{sm}} \sin (\theta)$ in each sector leads to the expressions of the duty cycles shown in Table 2 . The SVPWM principle is employed to produce a periodic voltage, whose rms value equals $V_{s}$, by generating $V_{k}$ and $V_{k+1}$ such that $\mathrm{T}_{\mathrm{k}}=\mathrm{d}_{\mathrm{k}} \mathrm{T}_{\mathrm{s}}$ and $\mathrm{T}_{\mathrm{k}+1}=\mathrm{d}_{\mathrm{k}+1} \mathrm{~T}_{\mathrm{s}}$ respectively, for every sampling period $T_{s}$. Since $d_{k}+d_{k+1} \leq 1$, the voltages $V_{0}$ through $V_{7}$ must be hexagonally enveloped over the switching period $\mathrm{T}_{\mathrm{s}}$. Though several solutions are possible, the one which minimizes the total harmonic distortion (THD) of the stator current emerges by applying $\mathrm{V}_{\mathrm{o}}$ and $\mathrm{V}_{7}$ during the same duration $\mathrm{T}_{\mathrm{o}}=\mathrm{T}_{7}=\frac{1-\mathrm{d}_{\mathrm{k}}-\mathrm{d}_{\mathrm{k}+1}}{2} \mathrm{~T}_{\mathrm{s}}$.

$\mathrm{V}_{\mathrm{o}}$ is equally applied at the beginning and at the end of the switching period, where as $V_{7}$ is applied in the middle. 
Table 2. Expressions of the duty cycles in each sector

\begin{tabular}{|c|c|c|c|}
\hline Sector No. & $\theta$ & $d_{k}$ & $d_{k+1}$ \\
\hline 1 & {$\left[0, \frac{\pi}{3}\right]$} & $\frac{2}{\sqrt{3}} \times \frac{\mathrm{V}_{\mathrm{s}}}{\mathrm{E}} \times \sin \left(\frac{\pi}{3}-\theta\right)$ & $\frac{2}{\sqrt{3}} \times \frac{\mathrm{V}_{\mathrm{s}}}{\mathrm{E}} \times \sin (\theta)$ \\
\hline 2 & {$\left[\frac{\pi}{3}, \frac{2 \pi}{3}\right]$} & $\frac{2}{\sqrt{3}} \times \frac{\mathrm{V}_{\mathrm{s}}}{\mathrm{E}} \times \sin \left(\frac{\pi}{3}+\theta\right)$ & $\frac{2}{\sqrt{3}} \times \frac{\mathrm{V}_{\mathrm{s}}}{\mathrm{E}} \times \sin \left(\frac{5 \pi}{3}+\theta\right)$ \\
\hline 3 & {$\left[\frac{2 \pi}{3}, \pi\right]$} & $\frac{2}{\sqrt{3}} \times \frac{\mathrm{V}_{\mathrm{s}}}{\mathrm{E}} \times \sin (\theta)$ & $\frac{2}{\sqrt{3}} \times \frac{\mathrm{V}_{\mathrm{s}}}{\mathrm{E}} \times \sin \left(\frac{4 \pi}{3}+\theta\right)$ \\
\hline 4 & {$\left[\pi, \frac{4 \pi}{3}\right]$} & $\frac{2}{\sqrt{3}} \times \frac{\mathrm{V}_{\mathrm{s}}}{\mathrm{E}} \times \sin \left(\frac{5 \pi}{3}+\theta\right)$ & $\frac{2}{\sqrt{3}} \times \frac{\mathrm{V}_{\mathrm{s}}}{\mathrm{E}} \times \sin (2 \pi-\theta)$ \\
\hline 5 & {$\left[\frac{4 \pi}{3}, \frac{5 \pi}{3}\right]$} & $\frac{2}{\sqrt{3}} \times \frac{\mathrm{V}_{\mathrm{s}}}{\mathrm{E}} \times \sin \left(\frac{4 \pi}{3}+\theta\right)$ & $\frac{2}{\sqrt{3}} \times \frac{\mathrm{V}_{\mathrm{s}}}{\mathrm{E}} \times \sin \left(\frac{\pi}{3}-\theta\right)$ \\
\hline 6 & {$\left[\frac{5 \pi}{3}, 2 \pi\right]$} & $\frac{2}{\sqrt{3}} \times \frac{\mathrm{V}_{s}}{\mathrm{E}} \times \sin (2 \pi-\theta)$ & $\frac{2}{\sqrt{3}} \times \frac{\mathrm{V}_{\mathrm{s}}}{\mathrm{E}} \times \sin \left(\frac{\pi}{3}+\theta\right)$ \\
\hline
\end{tabular}

Table 3. Time functions for SVPWM technique

\begin{tabular}{|c|c|c|c|}
\hline Sector No. & $\mathrm{T}_{\mathrm{a}}$ & $\mathrm{T}_{\mathrm{b}}$ & $\mathrm{T}_{\mathrm{c}}$ \\
\hline 1 & $\frac{\mathrm{T}_{\mathrm{s}}-\mathrm{T}_{1}-\mathrm{T}_{2}}{4}$ & $\frac{\mathrm{T}_{\mathrm{s}}+\mathrm{T}_{1}-\mathrm{T}_{2}}{4}$ & $\frac{\mathrm{T}_{\mathrm{s}}+\mathrm{T}_{1}+\mathrm{T}_{2}}{4}$ \\
\hline 2 & $\frac{\mathrm{T}_{\mathrm{s}}-\mathrm{T}_{1}+\mathrm{T}_{2}}{4}$ & $\frac{\mathrm{T}_{\mathrm{s}}-\mathrm{T}_{1}-\mathrm{T}_{2}}{4}$ & $\frac{\mathrm{T}_{\mathrm{s}}+\mathrm{T}_{1}+\mathrm{T}_{2}}{4}$ \\
\hline 3 & $\frac{\mathrm{T}_{\mathrm{s}}+\mathrm{T}_{1}+\mathrm{T}_{2}}{4}$ & $\frac{\mathrm{T}_{\mathrm{s}}-\mathrm{T}_{1}-\mathrm{T}_{2}}{4}$ & $\frac{\mathrm{T}_{\mathrm{s}}+\mathrm{T}_{1}-\mathrm{T}_{2}}{4}$ \\
\hline 4 & $\frac{\mathrm{T}_{\mathrm{s}}+\mathrm{T}_{1}+\mathrm{T}_{2}}{4}$ & $\frac{\mathrm{T}_{\mathrm{s}}-\mathrm{T}_{1}+\mathrm{T}_{2}}{4}$ & $\frac{\mathrm{T}_{\mathrm{s}}-\mathrm{T}_{1}-\mathrm{T}_{2}}{4}$ \\
\hline 5 & $\frac{\mathrm{T}_{\mathrm{s}}+\mathrm{T}_{1}-\mathrm{T}_{2}}{4}$ & $\frac{\mathrm{T}_{\mathrm{s}}+\mathrm{T}_{1}+\mathrm{T}_{2}}{4}$ & $\frac{\mathrm{T}_{\mathrm{s}}-\mathrm{T}_{1}-\mathrm{T}_{2}}{4}$ \\
\hline 6 & $\frac{\mathrm{T}_{\mathrm{s}}-\mathrm{T}_{1}-\mathrm{T}_{2}}{4}$ & $\frac{\mathrm{T}_{\mathrm{s}}+\mathrm{T}_{1}+\mathrm{T}_{2}}{4}$ & $\frac{\mathrm{T}_{\mathrm{s}}-\mathrm{T}_{1}+\mathrm{T}_{2}}{4}$ \\
\hline & & & \\
\hline
\end{tabular}

The duty cycles can be written in a unified way as $\mathrm{d}_{\mathrm{k}}=\frac{2 \mathrm{~V}_{\mathrm{sm}}}{\sqrt{3} \mathrm{E}} \sin \left(\theta^{\prime \prime}\right) \quad$ and $\mathrm{d}_{\mathrm{k}+1}=\frac{2 \mathrm{~V}_{\mathrm{sm}}}{\sqrt{3} \mathrm{E}} \sin \left(\theta^{\prime}\right), \quad$ with $\quad \theta^{\prime \prime}=\frac{\pi}{3}-\theta^{\prime}$ and $_{\theta^{\prime}=\theta-(k-1) \frac{\pi}{3}}$. Since these expressions no longer depend on the sector number, they are denoted as $d_{1}$ and $d_{2}$ and the corresponding times as $T_{1}$ and $T_{2}$. The time functions $T_{a}, T_{b}$ and $\mathrm{T}_{\mathrm{c}}$ can be obtained from Table 3 .

\section{CURRENT CONTROLLED}

\section{ALGORITHMS}

The block diagram of SVPWM current control algorithm is as shown in Figure 4.The reference currents $\left(I_{\text {ref }}\right)$ are generated by using PI controller, speed feedback $\left(\mathrm{w}_{\mathrm{r}}\right)$ and reference speed $\left(\mathrm{w}_{\mathrm{r}}{ }^{*}\right)$. The actual values of the three stator currents are measured, compared with the reference currents and the errors $\left(i_{e}\right)$ computed. These error currents are compared with a triangular wave and the corresponding gate signals are obtained as shown in Figure 5.

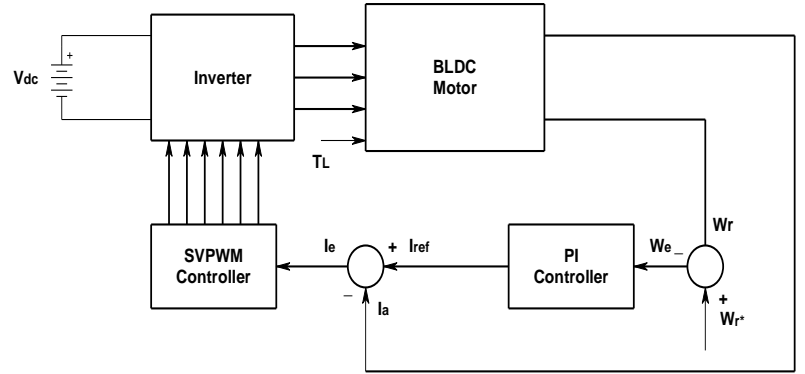

Fig 4: Block diagram of SVPWM current control algorithm

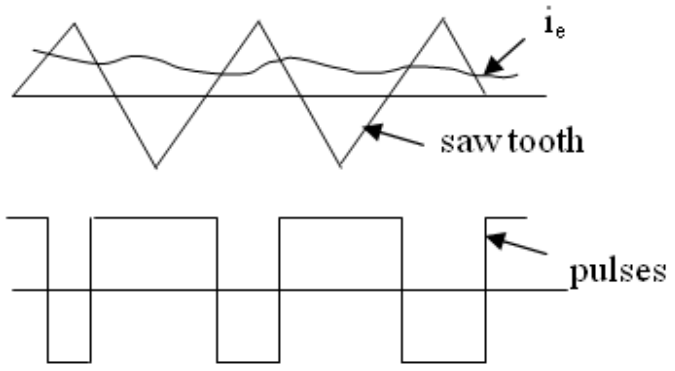

Fig 5: Comparison of current error and saw tooth waveform

The proposed algorithm, based on the use of the SVPWM technique is explained in Figure 2. The time functions are obtained from the SVPWM technique as shown in Figure 6 (a). These time functions are multiplied with their corresponding current errors and a new reference is generated as shown in Figure 6 (b).

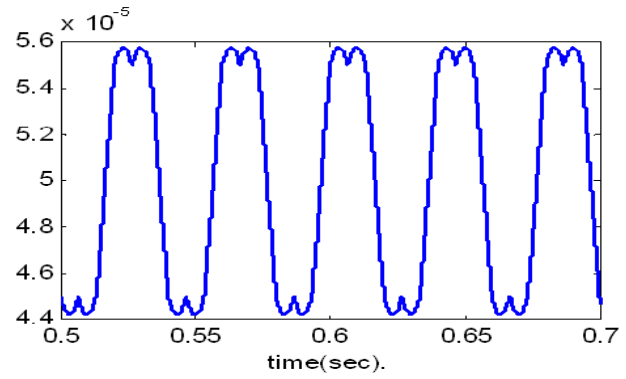

(a)Time function $T_{a}$ 


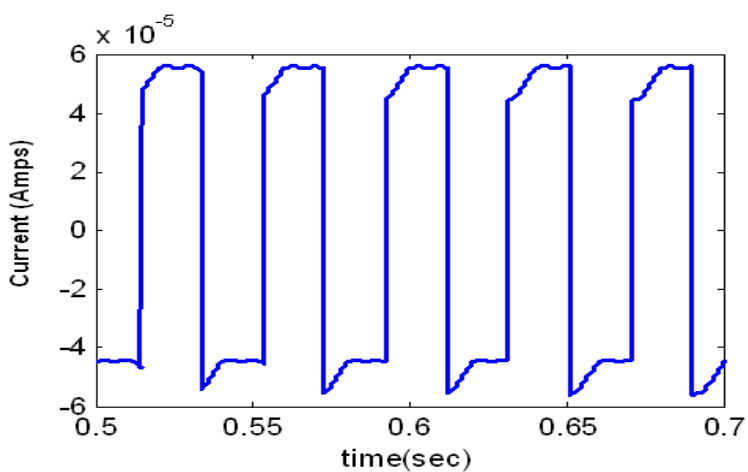

(b) Reference waveform

Fig 6: Obtaining CCSVPWM reference function

This reference waveform is compared with a triangular wave and the corresponding gate signals are obtained .The comparison will result in a voltage control signal that goes to the gates of the voltage source inverter to generate the desire output. Its control will respond according to the error. If the error command is greater than the triangle waveform, the inverter leg is held switched to the positive polarity (upper switch on). When the error command is less than the triangle waveform, the inverter leg is switched to the negative polarity (lower switch on). The inverter leg is forced to switch at the frequency of the triangle wave and produces an output voltage proportional to the current error command.

\section{SIMULATION RESULTS}

The simulation is performed using MATLAB/SIMULINK on a standard BLDC motor whose parameters are seen in Table 4 , for an average load torque of $3 \mathrm{Nm}$.

Table 4. Parameters of BLDC motor

\begin{tabular}{|l|l|}
\hline Rated Voltage & $150 \mathrm{~V}$ \\
\hline Rated Current & $5 \mathrm{~A}$ \\
\hline Rated Torque & $3 \mathrm{~N}-\mathrm{m}$ \\
\hline Resistance & $0.388 \Omega$ \\
\hline Magnetizing Inductance & $13 \mathrm{mH}$ \\
\hline Back EMF Constant & $0.42 \mathrm{~V} /(\mathrm{rad} / \mathrm{sec})$ \\
\hline Poles & 2 \\
\hline
\end{tabular}

\subsection{Conventional method}

The simulated results of phase current $\left(\mathrm{I}_{\mathrm{abc}}\right)$, back emf $\left(\mathrm{E}_{\mathrm{abc}}\right)$, speed $(\mathrm{N})$ and torque (T) waveforms for the conventional method are shown in Figure 7. The motor is allowed to run at $1500 \mathrm{rpm}$ and the trapezoidal back emf waveform has a maximum value of $64 \mathrm{~V}$, while the quasi-rectangular phase current is with a maximum value of $4.8 \mathrm{~A}$. The load torque vacillates between $2.08 \mathrm{Nm}$ to $3.78 \mathrm{Nm}$, resulting in a torque ripple of $29.01 \%$. The THD of the phase current is $24.33 \%$.
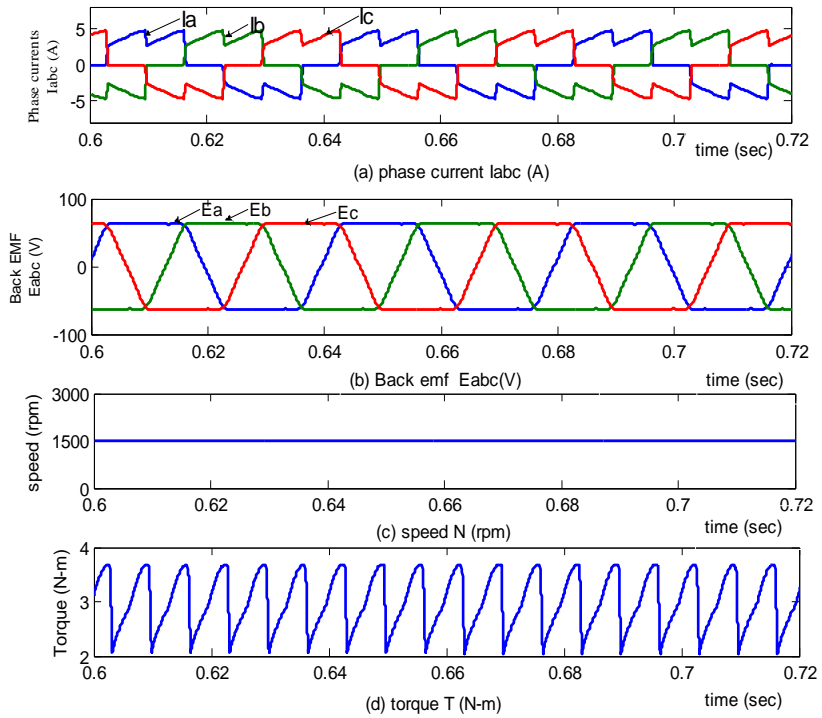

Fig 7: Current, back emf, speed and torque waveforms with conventional method

\subsection{Unipolar PWM method}

The phase current $\left(\mathrm{I}_{\mathrm{abc}}\right)$, back emf $\left(\mathrm{E}_{\mathrm{abc}}\right)$, speed $(\mathrm{N})$ and torque (T) waveforms for the unipolar PWM method is shown in Figure 8. The vacillation in the shaft torque is from $2.2 \mathrm{Nm}$ to $3.6 \mathrm{Nm}$ with a ripple of $24.13 \%$. This method results in an improved phase current than the conventional method and hence paves the way to reduce the torque ripple. The THD of the phase current is $24.19 \%$.
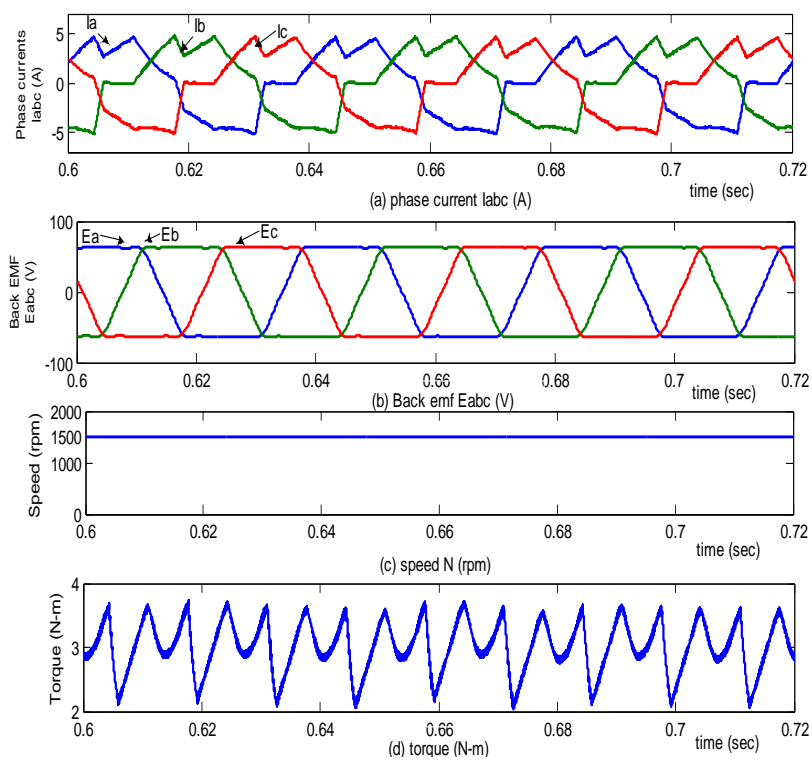
Fig 8: Current, back emf, speed and torque waveforms with unipolar PWM method

\subsection{Bipolar PWM method}

The performance of a bipolar PWM method as seen from Figure 9 illustrates the reduced vacillation of shaft torque (from $2.5 \mathrm{Nm}$ to $3.5 \mathrm{Nm}$ ) and ripple $(33.67 \%)$. The THD of the phase current is also reduced to $16.67 \%$
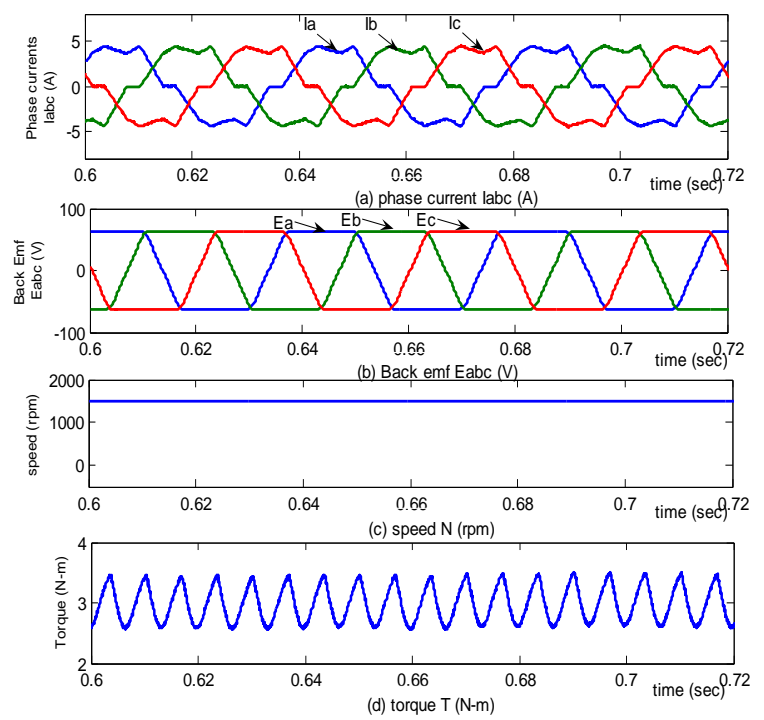

Fig 9: Current, back emf, speed and torque waveforms with Bipolar PWM method

\subsection{Varying input voltage method}

Fig.10 shows the simulated results of phase current (Iabc), back emf (Eabc), speed $(\mathrm{N})$ and torque (T) waveforms for varying input voltage method. Shaft torque varies from $2.5 \mathrm{~N}-\mathrm{m}$ to 3.4 $\mathrm{N}-\mathrm{m}$ while the torque ripple is $15.25 \%$ and phase current THD is $21.68 \%$.
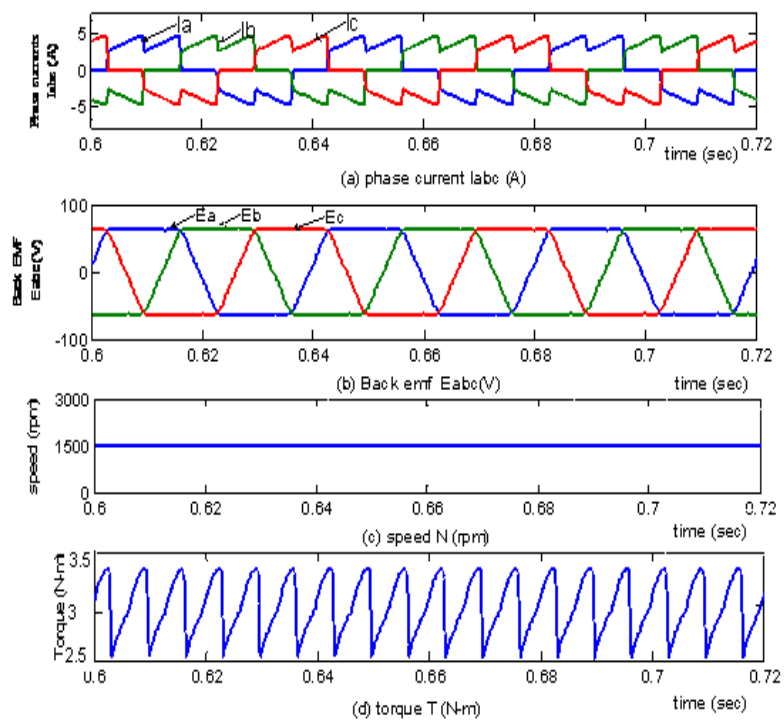

Fig 10: Current, back emf, speed and torque waveforms with VIVM

\subsection{CCSVPWM Technique}

Figure 11 shows the steady state simulated results of phase current $\left(\mathrm{I}_{\mathrm{abc}}\right)$, back emf $\left(\mathrm{E}_{\mathrm{abc}}\right)$, speed $(\mathrm{N})$ and torque $(\mathrm{T})$ waveforms for CCSVPWM approach with the PI controller. The shaft torque varies from $2.64 \mathrm{Nm}$ to $3.45 \mathrm{Nm}$ while the torque ripple is $13.3 \%$ and the phase current THD is 9.84 $\%$.
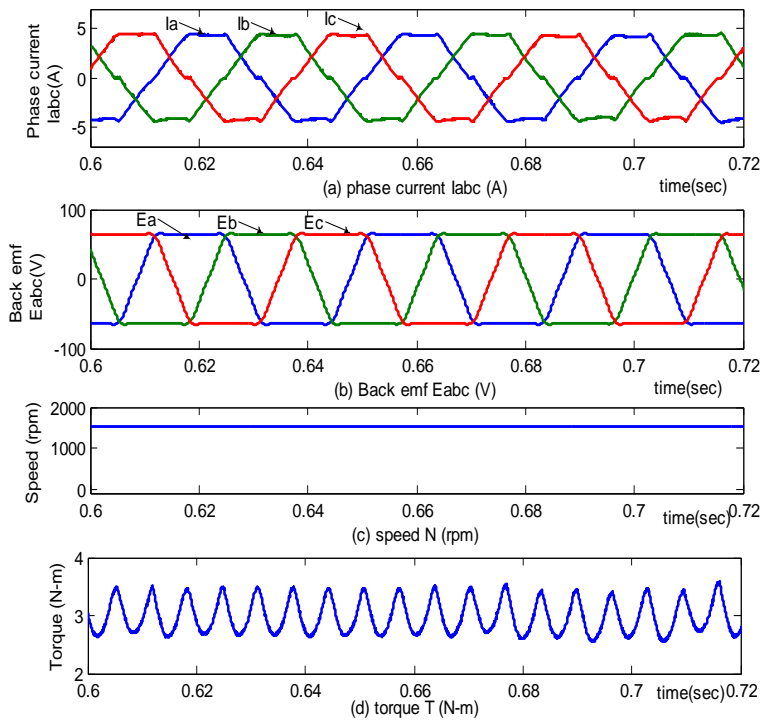

Fig 11: Current, back emf, speed and torque waveforms with CCSVPWM

The comparison of results of both CCA and CCSVPWM are presented in Table 5. It follows that the torque ripple is higher for the conventional method over the unipolar and bipolar PWM methods. The CCSVPWM performs significantly better by a measure of $50 \%$ in terms of torque ripple and phase current distortion.

Table 5. Performance evaluation of ripple reduction techniques

\begin{tabular}{|c|c|c|c|}
\hline Method & $\begin{array}{c}\text { Shaft } \\
\text { torque }(\mathrm{Nm})\end{array}$ & $\begin{array}{c}\text { Torque } \\
\text { ripple(\%) }\end{array}$ & $\begin{array}{c}\text { THD of phase } \\
\text { current(\%) }\end{array}$ \\
\hline Conventional & $2.08-3.78$ & 29.01 & 24.33 \\
\hline Unipolar PWM & $2.2-3.6$ & 24.13 & 24.19 \\
\hline Bipolar PWM & $2.5-3.5$ & 16.67 & 13.24 \\
\hline VIVM & $2.5-3.4$ & 15.25 & 21.68 \\
\hline CCSVPWM & $2.64-3.45$ & 13.30 & 9.84 \\
& & & \\
\hline
\end{tabular}




\section{TRANSIENT PERFORMANCE}

The phase current $\left(\mathrm{I}_{\mathrm{abc}}\right)$, back emf $\left(\mathrm{E}_{\mathrm{abc}}\right)$, speed $(\mathrm{N})$ and torque (T) waveforms are displayed in Figure 12, when a step change in load is introduced. The shaft torque is allowed to vary suddenly from $3 \mathrm{Nm}$ to $1 \mathrm{Nm}$. The PI controller enables the speed of the motor to settle at its steady state value, after the load disturbance, with in a reasonable time frame. The torque ripple is $18 \%$ when the load torque is $1 \mathrm{Nm}$ and $13.3 \%$ when the load torque is $3 \mathrm{Nm}$. Figure 13 shows the speed changes for the same disturbance.
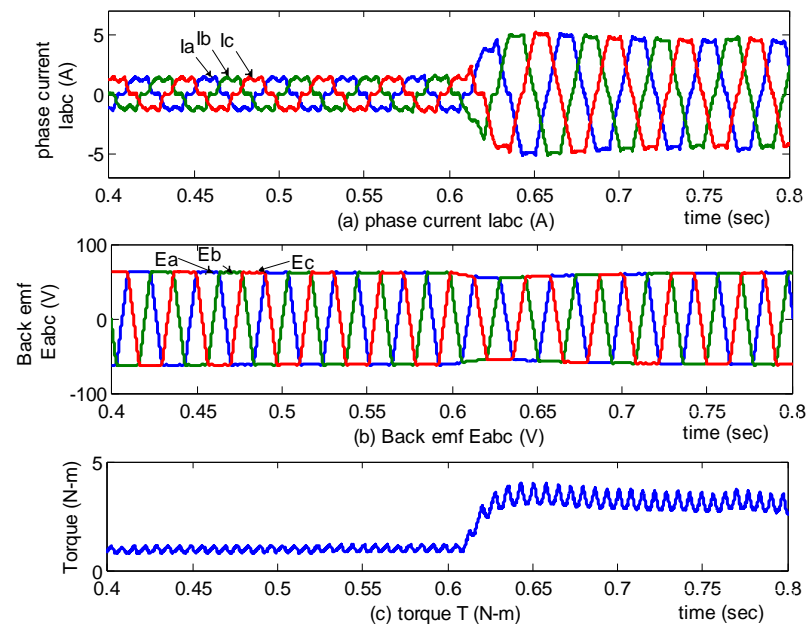

Fig 12: Current, back emf, speed and torque waveforms with CCSVPWM

\section{CONCLUSION}

The current control algorithms and the CCSVPWM methods suitable for a BLDC motor drive are evaluated with relevant waveforms and their effectiveness in torque ripple reduction has been highlighted. The phase current distortion, which is the prime cause for torque ripple in the conventional algorithms has been computed. The ability of the motor to perform satisfactorily both during steady state and transient conditions has been brought out. The CCSVPWM method, which is found to be more efficient in reducing the torque ripples, will serve to enhance the usage of BLDC motor drives in electromechanical actuators.

\section{REFERENCES}

[1] P.Pillay and R.Krishnan, "Modeling, simulation, and analysis of permanent-magnet motor drives, part II: The brushless dc motor drive," IEEE Trans.Ind.Appl.,vol.IA25,no.2,pp.274-279,Mar./Apr.1989.

[2] J. R. Hendershot JR, THE Miller, Design of Brushless Permanent Magnet Motors, 1rd ed., Oxford Magna Physics:1994, pp. 5-1 - 5-44, 10-1 - 10-14.

[3] Jahns T. M., Soong W. L., "Pulsating Torque Minimization Techniques for Permanent Magnet AC Motor Drives---A Review," IEEE Transactions on Industrial Electronics, Vol. 43, No. 2, April 1996, pp. 321-330.
[4] Joong-Ho Song, Ick Choy, "Commutation Torque Ripple Reduction in Brushless DC Motor Drives Using a Single DC Current Sensor," IEEE Transactions on Power Electronics, Vol. 19, No. 2, March 2004, pp. 312-319.

[5] R Carlson, M. Lajoie-Mazenc, and J. C. S. Fagundes, "Analysis oftorque ripple due to phase commutation in brushless DC machines,' IEEE Trans. Ind. Applicat., vol. 28, pp. 632--638, May/June 1992.

[6] T. M. Jahns andW. L. Soong, "Pulsating torque minimization techniques for permanent magnet AC motor drives-----a review," IEEE Trans. Ind. Electron., vol. 43, pp. 321--330, Apr. 1996.

[7] Y. Liu, Z. Q. Zhu, and D. Howe, "Commutation-TorqueRipple Minimization in Direct-Torque-Control PM Brushless DC Drives," IEEE Trans. Ind. Applicat., vol. 43, pp. 1012-1017, July/August 2007.

[8] J. H. Soong, and I. Choy, "Commutation Torque Ripple Minimization in Brushless DC motor using a single DC current sensor," IEEE Trans.Power.Electron, Vol. 19, no.2, pp. 312-319, March 2004.

[9] Y. Sozer and D. A. Torrey, "Adaptive torque ripple control of permanent magnet brushless DC motors," Proc. 13th Annual Applied Power Electronics Conference and Exposition, Vol.1, 15-19 Feb. 1998, pp.86- 92.

[10] C.T.Pan and E. Fang, "A phase-locked-loop-assisted internal model adjustable-speed controller for BLDC motors, " IEEE Trans. on Industrial Electronics, Vol.55,No.9,pp.3415-3425, 2008.

[11] K.Y.Nam, W.T. Lee, C.M.Lee and J.P.Hong, "Reducing torque ripple of brushless DC motor by varying input voltage ," IEEE Trans.on Magnetics, Vol.42, No.4, pp.1307-1310,2006.

[12] J.Cao, B.Cao, P.Xu, S.Zhou, G.Guo and X.Wu, “ Torque ripple control of position-sensorless brushless DC motor based on neural network identification,"in Proc.of IEEE ICIEA, pp.752-757, 2008.

[13] Yong Liu, Z. Q. Zhu, "Commutation-Torque-Ripple Minimizationin Direct-Torque-Controlled PM Brushless DC Drives," IEEE trans.Industry Applications, Vol. 43, No. 4, August 2007. PP 1012- 1021.

[14] Zhi Yang Pan, and Fang Lin Luo, "Novel resonant pole inverter for Brushless DC motor drive system," IEEE Trans on Power Electronics, Vol. 20, No. 1, Jan 2005. PP 173181.

[15] Z.Cunshan, B.Dunxin , "A PWM Control Algorithm for Eliminating Torque Ripple Caused by Stator Magnetic Field Jump of Brushless DC Motors," in Intelligent Control and Automation, 2008. WCICA 2008. 7th World Congress on, 2008, pp. 6547-6549.

[16] Y.Murai, "Torque Ripple Improvement for Brushless DC Miniature Motors," IEEE Trans. on Industry Applications on 25 (1989), 441-450.

[17] X.Zhang, B.Chen, "Influences of PWM Mode on the Current Generated by BEMF of Switch-Off Phase in Control System of BLDC Motor," in Electrical Machines and Systems, 2001.ICEMS 2001. Proceedings of the Fifth International Conference on, 2001, vol.1, pp. 579-582 
[18] H.Lu, L.Zhang and W.Qu, "A new torque control method for torque ripple minimization of BLDC motors with unideal back EMF,"IEEE Trans. on Power Electronics, Vol.21, No.6, pp.1762-1768, 2006.

[19] Y.Liu, Z.Q.Zhu and D. Howe, "Commutation-torque-ripple minimization in direct-torque-controlled PM brushless DC drives," IEEE Trans. on Industry Applications, Vol.43, No.4, pp.1012-1021, 2007.

[20] S.S.Bharatkar, R. Yanamshetti, D.Chatterijee and A.K. Ganguli, "Reduction of commutation torque ripple in a brushless DC motor drive," in Proc.of IEEE PEcon,pp.289294, 2008.
[21] Y.S.Lai, F.S.Shyu and Y.K.Lin, " Novel PWM technique without causing reversal DC-link current for brushless DC motor drives with bootstrap driver," in Proc.of IEEE IAS, Vol.3,pp.2182-2188, 2005.

[22] Y.S.Lai and Y.K.Lin, "Assessment of pulse-width modulation technique for brushless DC motor drives," in Proc.of IEEE IAS, Vol.4,pp.1629-1636, 2006.

[23] H.Karimi-Davijani, A.Sheikholeslami, R. Ahmadi, and H. Livani, "Active and reactive power control of DFIG using SVPWM converter," in Proc.of IEEE UPEC, pp.1-5, 2008. 